\title{
Influence of Reactive Volatile Organic Compounds on Ozone Production in Houston-Galveston-Brazoria Area
}

\author{
Samarita Sarker ${ }^{1,2}$, Raghava R. Kommalapati1,2*, Ziaul Huque ${ }^{1,3}$ \\ ${ }^{1}$ NSF CREST Center for Energy \& Environmental Sustainability, Prairie View A \& M University, Prairie View, TX, \\ USA \\ ${ }^{2}$ Department of Civil and Environmental Engineering, Prairie View A \& M University, Prairie View, TX, USA \\ ${ }^{3}$ Department of Mechanical Engineering, Prairie View A \& M University, Prairie View, TX, USA \\ Email: ${ }^{*}$ rrkommalapati@pvamu.edu
}

Received 6 February 2015; accepted 24 April 2015; published 27 April 2015

Copyright (C) 2015 by authors and Scientific Research Publishing Inc.

This work is licensed under the Creative Commons Attribution International License (CC BY). http://creativecommons.org/licenses/by/4.0/

(c) (7) Open Access

\section{Abstract}

Secondary pollutant ozone $\left(\mathrm{O}_{3}\right)$ formation in a particular area is often influenced by various factors. Source of emissions is one of the factors. In south east Texas, Houston-Galveston-Brazoria (HGB) is a marginal non-attainment area for ozone $\left(\mathrm{O}_{3}\right)$. A summer episode of May 28 to July 2, 2006 is simulated using Comprehensive Air Quality Model with extensions (CAMx). During this period $\mathrm{O}_{3}$ concentration in HGB often exceeds the National Ambient Air Quality Standards (NAAQS) $0.075 \mathrm{ppm}$ of average 8 hour $\mathrm{O}_{3}$ concentration. HGB area has numerous point sources. Various studies found that some specific volatile organic compounds are very reactive in atmosphere. The objective of this study is to analyze the influence of volatile organic compounds present in point source emissions on the air quality of HGB area. For this purpose ozone sensitivity for HGB area is analyzed by the ratio of hydrogen peroxides $\left(\mathrm{H}_{2} \mathrm{O}_{2}\right)$ to nitric acid $\left(\mathrm{HNO}_{3}\right)$. $\mathrm{HGB}$ area is found NOx limited but reactive VOCs are found to be influential too. From (1-4 June, 2006) maximum $\mathrm{O}_{3}$ concentration was found on weekend, June 3. VOCs such as Acetaldehyde $\left(A L D_{2}\right)$, Formaldehyde (FORM) and Alkane (ETHA) showed good correlation with $\mathrm{O}_{3}$ concentrations on that day. In addition, Peroxyacetyl nitrate (PAN) formation was found correlated to higher ozone production. Criteria pollutant Sulfur dioxide $\left(\mathrm{SO}_{2}\right)$ was found to influence the $\mathrm{ALD}_{2}$ and ETHA concentrations, and thus indirectly influenced $\mathrm{O}_{3}$ production.

\section{Keywords}

Comprehensive Air Quality Model with Extensions (CAMx), Nitrogen Oxides $\left(\mathrm{NO}_{\mathrm{x}}\right)$ Ozone $\left(\mathrm{O}_{3}\right)$, Volatile Organic Compound (VOC), Correlation of VOC with $\mathrm{O}_{3}$

\footnotetext{
${ }^{*}$ Corresponding author.
}

How to cite this paper: Sarker, S., Kommalapati, R.R. and Huque, Z. (2015) Influence of Reactive Volatile Organic Compounds on Ozone Production in Houston-Galveston-Brazoria Area. Journal of Environmental Protection, 6, 399-408. 


\section{Introduction}

Air pollution is a great challenge for Houston Galveston Brazoria (HGB) area. This area consists of eight counties: Brazoria, Chamber, Fort Bend, Galveston, Harris, Liberty, Montgomery and Waller. Rapid urbanization and industrialization with meteorological variability has taken alarming dimensions for air quality of this area. This area is classified as marginal nonattainment as per 2008 eight-hour ozone NAAQS of 75 ppb [1] [2]. The air quality of HGB area includes contribution of numerous emission sources. For instance, point source, area source, mobile source, non-road source and biogenic source are the main sources of emissions in this area. These sources release various pollutants, such as Nitrogen Oxides $\left(\mathrm{NO}_{\mathrm{x}}\right)$, Volatile Organic Compounds (VOCs), Carbon Monoxide (CO), Sulfur Dioxide $\left(\mathrm{SO}_{2}\right)$ etc. Among these pollutants $\mathrm{NO}_{\mathrm{x}}$ and VOCs are the major Ozone$\left(\mathrm{O}_{3}\right)$ precursors [3].

A study [4] reported that apart from the meteorological parameters, emission inventory input has long been recognized as the most predominant factor for air quality problems including ground-level $\mathrm{O}_{3}$ formation. In other words $\mathrm{O}_{3}$ formation is very sensitive to the emission quantity, speciation distribution of the precursors such as VOC/NOx ratio, and other chemical interactions among the emitted pollutants. Houston is an urban area and South East Houston has many petrochemical plants that are situated along the shore. So, this area is a unique mix of pollution emissions activities [5] [6] combined with summer time meteorology dominated by irregular coastline effects. The rapid production of high $\mathrm{O}_{3}$ concentrations close to the sources is also noticeable [7]. From NOAA Earth System Research Laboratory (ESRL) point source inventory, it was found that there are about 506 point source emission sites in HGB area [8]. For episode of May 28 to July 2, 2006, peak ozone concentration mostly varied from $110 \mathrm{ppb}$ to $120 \mathrm{ppb}$ in between 11:00 to 17:00 CST in HGB area. Point source emissions relatively remain similar during each weekday and weekend within a seasonal episode [9], so analysis was done for the representative weekdays (June 1, 2) and weekends (June 3, 4).

In between January 31, 2003 and January 30, 2004, total of $1887 \mathrm{O}_{3}$ exceedance events were reported in TCEQ Region 12, Houston [10] [11]. Approximately 40\% of these events were Highly Reactive Volatile Organic Compounds (HRVOCs) involved. Alkenes (ethene, propene, 1, 3-butadiene, 1-butene, isobutene, trans-2butene, cis-2-butene) are classified as HRVOCs [12]. A study mentioned that Formaldehyde (FORM) was a key species in understanding ozone related air pollution [13]. So, reactivity of these VOCs is important phenomena during $\mathrm{O}_{3}$ production. This paper evaluates the impact of point source emissions on $\mathrm{O}_{3}$ concentrations using EPS3 and CAMx simulation results. Further rigorous analysis was performed to isolate specific VOCs to be controlled for $\mathrm{O}_{3}$ exceedance in HGB area.

\section{Air Quality Models}

\subsection{Model Selection}

Comprehensive Air Quality Model with extensions (CAMx) is a 3-D photochemical grid model. In this studyCAMx 5.40 was used to estimate the air pollutants concentration in the troposphere. This version of CAMx uses chemical mechanism 7, known as CB6. This mechanism uses 218 reactions and up to 114 chemical species [14]. This model simulates the physical and chemical processes governing the formation and transport of Ozone. CAMx requires input data file of meteorology, emission, boundary condition and geography. Development of emissions input file for CAMx model is an integrated process. For example point source and area source emissions were processed in EPS3. Mobile source, biogenic source and non-road source data were generated by MOVES, GloBEIS and NON-ROAD model respectively. Meteorological and boundary condition data files were generated by the Weather Research and Forecasting (WRF) model and GEOS-Chem model.

For this paper, three emissions scenarios based upon point source emissions in HGB were simulated by CAMx 5.40. Point source emissions file for case HGB was generated using EPS3. After the simulation, CAMx output was visualized using tools like Visualization Environment Rich Data Interpretation (VERDI) [15].

\subsection{Modeling Domain}

In this work, CAMx Lambert Conformal Conic (LCC) map projection was used. CAMx uses nested grid domain for simulations, i.e. master grid input data move into finer grid input data. CAMx modeling domain parameters are shown in Table 1. While processing point source emission data in EPS3, information regarding the domain parameters was provided. Point source emissions data file for case HGB was generated for $36 \mathrm{~km}, 12 \mathrm{~km}$ and 4 
Table 1. Modeling domain for EPS3 and CAMx [16].

\begin{tabular}{ccccc}
\hline \multirow{2}{*}{ Domain $(\mathrm{km})$} & Easting (E) & Northing (N) & \multicolumn{2}{c}{ Number of cells } \\
\cline { 4 - 5 } & & & $(\mathrm{E})$ & 148 \\
rpo_36 & $-2735,2592$ & $-2088,1944$ & 149 & 110 \\
tx_12 & $-984,804$ & $-1632,-312$ & 191 & 218 \\
\hline tx_4 & $-328,436$ & $-1536,-644$ & & 190 \\
\hline
\end{tabular}

km for each day. Table 1 shows the detailed information for the modeling domain used in this study. Tx_4 km domain covers Houston-Galveston-Brazoria (HGB) area and portion of surrounding states (Figure 1). Due to lack of input data file for HGB sub-domain, tx_4 km data were used for data interpretation [16].

\section{Method}

This study is a continuation of a previous study [17] where three emissions scenarios (ALL, HGB and WOP) were developed to evaluate the impact of point source emissions on ground level Ozone $\left(\mathrm{O}_{3}\right)$ production in $\mathrm{HGB}$ area. For case ALL, TCEQ Rider 8 program generated emission input files were used. Emissions input file for case ALL includes all point source, area source, mobile source, non-road source and biogenic source emissions within the computational domain. Case HGB emissions input file includes the same mobile, non-road, biogenic source emission files as used in case ALL. Point source emissions file used for case HGB includes the emissions from the point sources that were present in eight counties of HGB area in 2006. For case WOP, same area, mobile, non-road and biogenic source emissions as used in case HGB were included but no point source emissions were considered. These emission input files were produced by EPS3 for $36 \mathrm{~km}, 12 \mathrm{~km}$ and $4 \mathrm{~km}$ grid domain. In this paper, more analysis has been performed to identify the important VOCs that effect the ozone production in HGB area from the CAMx outputs. Ozone sensitivity and correlation of VOCs with ozone is presented.

\section{Data Collection}

TCEQ modifies Texas Ozone Season Day (OSD) data by State of Texas Air Reporting System (STARS) and produces AIRS Facility Subsystem (AFS) archived ASCII file format which is compatible for Emission Processing System (EPS3). “afs.osd_2006_with_ards_removed_CB06_RPOlcp_v3” under Rider 8 program was used for case HGB point source emissions. Emissions files for area source, on-road source, non-road source and biogenic source were collected from TCEQ Rider 8 program [16] which was generated by EPS3, MOVES, NON-ROAD and GloBEIS model respectively [18]. Meteorological data and boundary condition data files generated by WRF and GOES-Chem models and these files were also collected from TCEQ [16]. For case ALL, HGB and WOP, same meteorological, boundary conditions, land use and other input files were used. Only emissions input files were developed for the different emissions scenarios by EPS3.

\section{CAMx Simulation}

EPS3 processed emission data and TCEQ files were used for CAMx simulations. Pollutants concentration in HGB area [(95 - 160) East grid cells and (65 - 120) North grid cells] were interpreted from CAMx tx_4 km domain results using VERDI tile plots.

Figure 2(a) shows the Ozone concentration for $4 \mathrm{~km}$ domain, whereas Figure 2(b) shows the interpreted HGB area for analysis at hour 13:00 (CST) on June 1, 2006. Maximum $\mathrm{O}_{3}$ concentration was found to be 0.101 ppm on that day. For analysis maximum concentrations of the pollutants for each hour of a day were achieved from these plots. For the simulated period, higher ground level ozone concentrations were observed in between 11:00 to 17:00 hours. Case ALL showed highest ozone $\left(\mathrm{O}_{3}\right)$ concentration among the three cases; case HGB showed higher $\mathrm{O}_{3}$ concentrations than case WOP for both weekdays and weekends. Decreased point sources emissions influenced the ozone production. Previous study [17] showed that about16\% ozone reduction can be achieved if point source emissions are at minimum. On the other hand, presence of point sources in HGB increases ( 3\%) ozone concentration [17]. Different studies also found that in a particular region ozone formation either increases with increasing NOx (NOx limited) or increasing VOCs (VOC limited). In 1995, Sillman [3] 


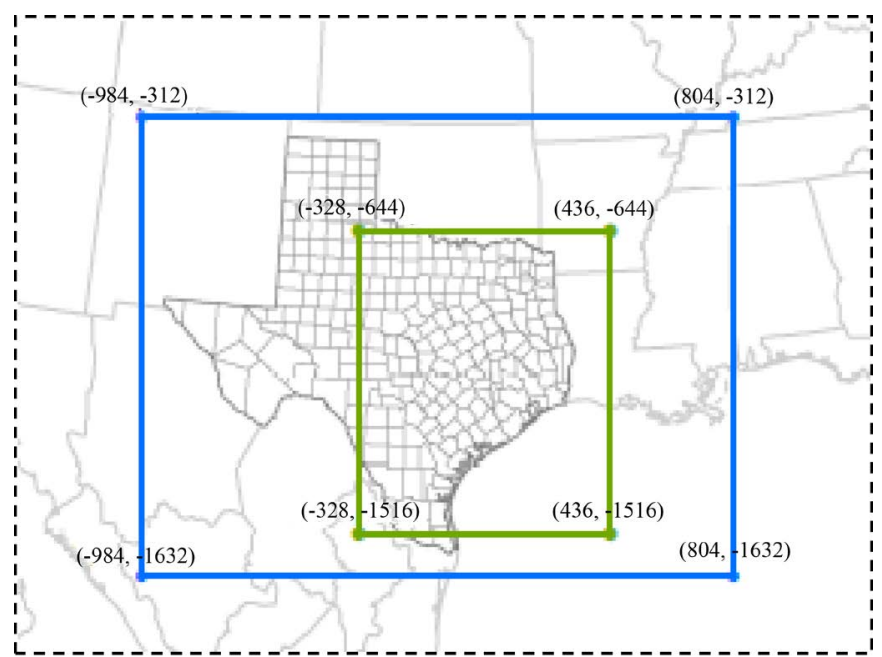

Figure 1. CAMx domain with co-ordinates of tx_12 km grid (blue rectangle) and tx_4 km grid (green rectangle) from where 8 counties of HGB area were interpreted.

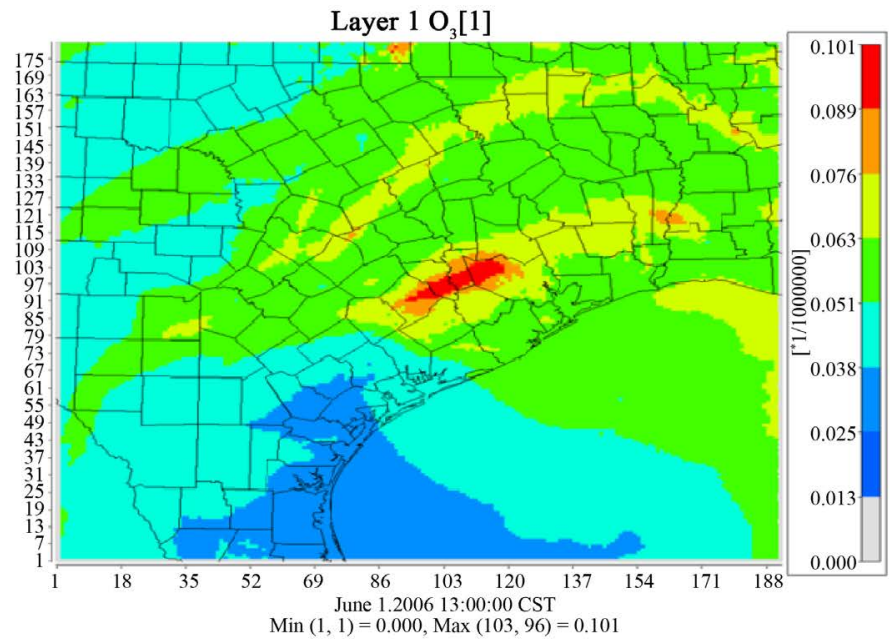

(a)
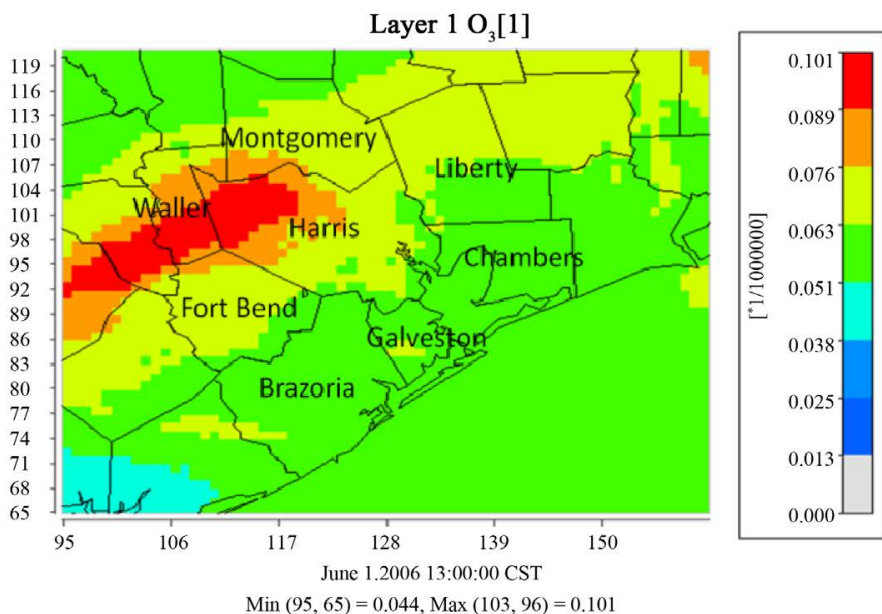

(b)

Figure 2. CAMx simulation to observe Ozone Concentration for June1, 2006. (a) 4 km grid domain; (b) Interpreted HGB area from tx_4 km grid domain. 
proposed that the ratio of hydrogen peroxides $\left(\mathrm{H}_{2} \mathrm{O}_{2}\right)$ to nitric acid $\left(\mathrm{HNO}_{3}\right)$ is the transition point and the indicator to find out to be whether Ozone formation in an area is NOx limited or VOC limited. Also, ENVIRON [14] explained that if $\mathrm{H}_{2} \mathrm{O}_{2} / \mathrm{HNO}_{3}$ is greater than (1/3), ozone formation in that area is NOx limited, which means Ozone formation depends on amount of NOx availability. If the ratio is less than (1/3) then it is vice versa. From CAMx output, concentrations of $\mathrm{H}_{2} \mathrm{O}_{2}$ and $\mathrm{HNO}_{3}$ were extracted for case ALL and case HGB. Ratio of $\mathrm{H}_{2} \mathrm{O}_{2} /$ $\mathrm{HNO}_{3}$ was found to be higher than 0.35 for almost every day (shown in Figure 3).

HGB area is found to be NOx limited for these days which means the ozone formation is dependent on NOx and should be relatively unaffected by changes in VOCs [3]. For the simulated episode maximum Ozone concentration was found on June 3, while NOx was highest on June 2, 2006. In another study [19] it was reported that ozone in rural area depends strongly on concentrations of NOx and almost independent of the amount of hydrocarbons present. But this condition is different for urban air, where ozone depends on both NOx and hydrocarbon. So, this indicates that even if NOx is key factor for ozone formation in HGB area but the activities of VOCs in atmosphere might influence the higher Ozone production.

From EPS3 message file of GRDEM module, it was found that point sources in HGB area release considerable amount of VOCs in lower atmosphere. Among the VOCs-Paraffin carbon bond (PAR), Terminal olefin carbon bond (OLE), Toluene and other monoalkyl aromatics (TOL), Xylene (XYL), Ethene (ETH) were emitted in large amounts (more than 5 tons/day). Formaldehyde (FORM), Acetaldehyde $\left(\mathrm{ALD}_{2}\right)$, Ethanol $(\mathrm{ETOH})$, Methanol $(\mathrm{MEOH})$, Ethane (ETHA), Propionaldehyde and higher Aldehydes $\left(\mathrm{ALD}_{\mathrm{X}}\right)$ were released in relatively smaller amounts (about 3 tons/day). The minimum emitted VOCs were Isoprene (ISOP) and Terpene (TERP),

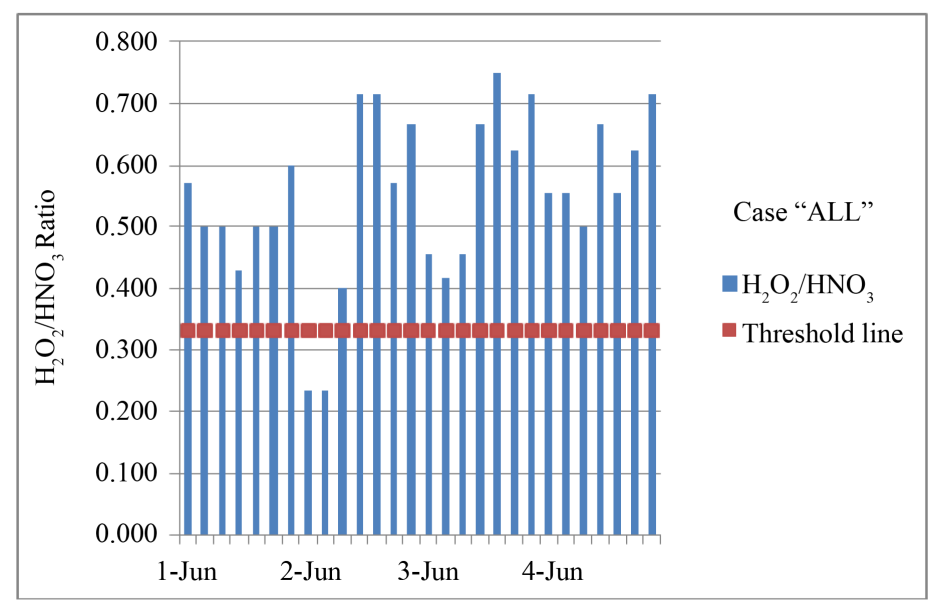

(a)

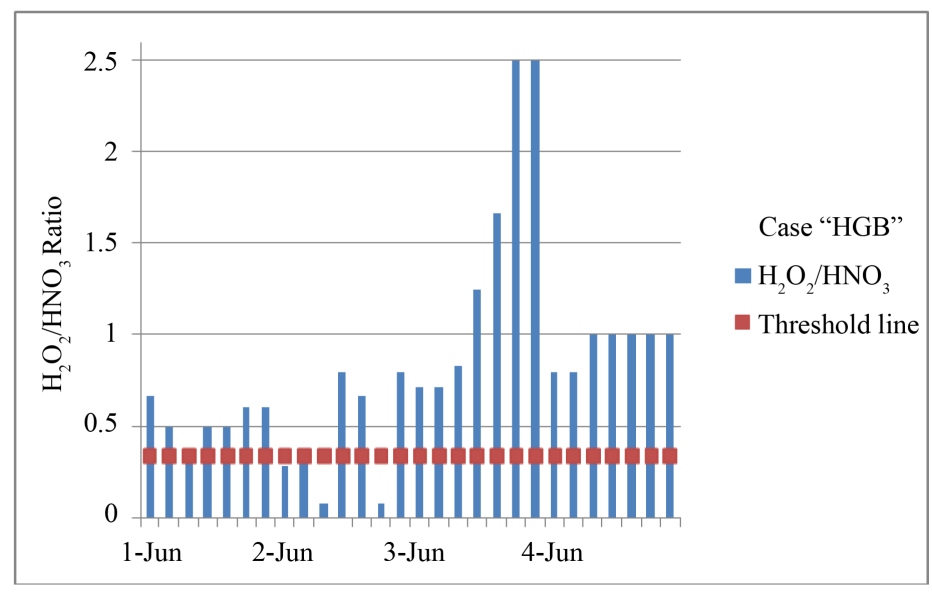

(b)

Figure 3. $\mathrm{H}_{2} \mathrm{O}_{2} / \mathrm{HNO}_{3}$ over the time steps (11:00 - 17:00 CST) from June 1-June 4, 2006. (a) Case ALL; (b) Case HGB. 
(less than 2 tons). For further study VOCs concentrations from CAMx output for June 3, 2006 were analyzed and concentration graphs are shown in Figure 4.

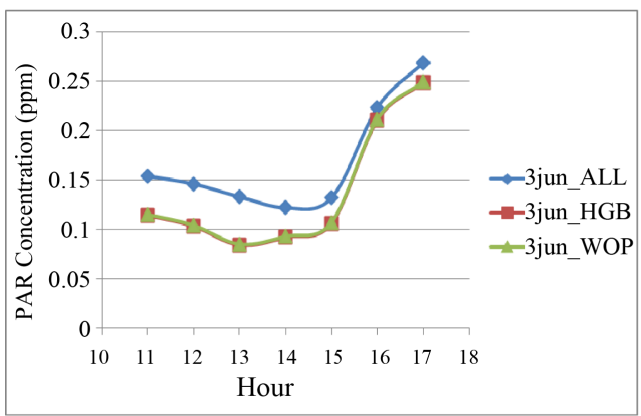

(a)

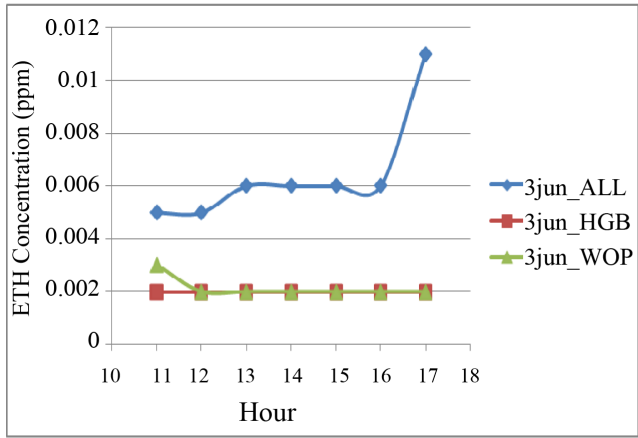

(c)

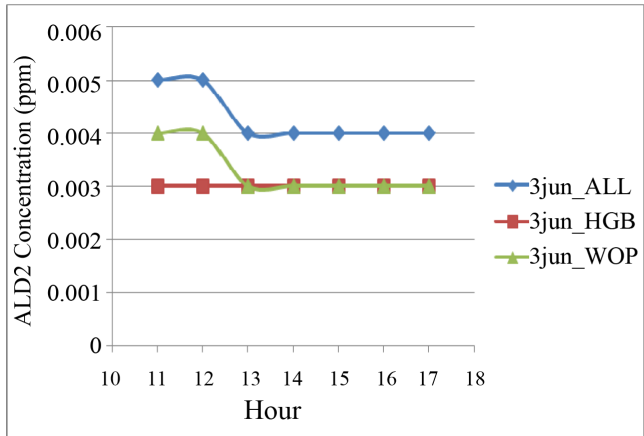

(e)

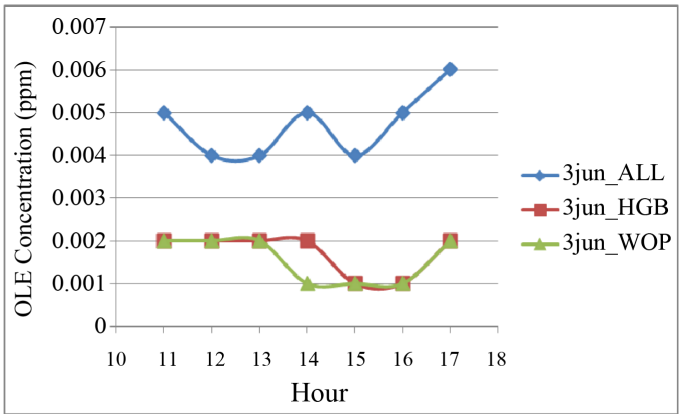

(b)

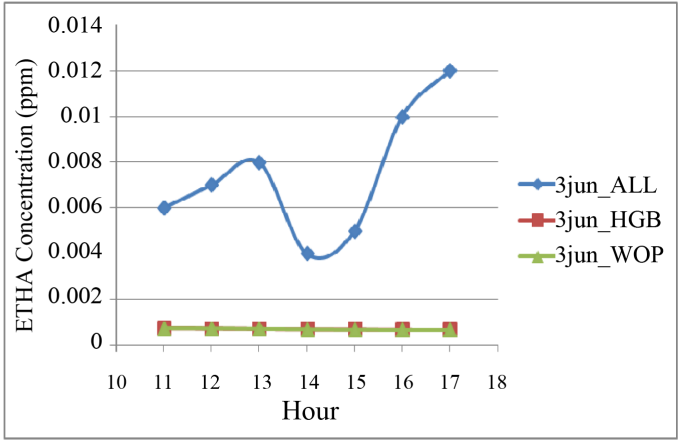

(d)

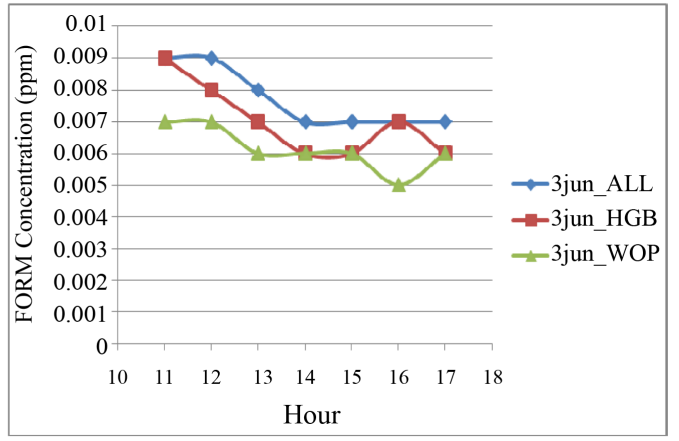

(f)

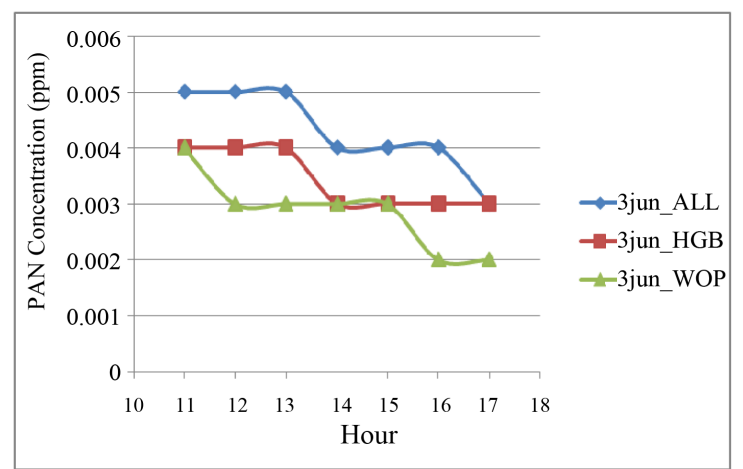

$(\mathrm{g})$

Figure 4. Concentration of pollutants from CST (excluding the daylight saving) 11:00 - 17:00 on June 3 for all three scenario. (a) PAR; (b) OLE; (c) ETH; (d) ETHA; (e) $\mathrm{ALD}_{2}$; (f) FORM; (g) PAN. 
In Figures 4(a)-(c), concentrations of PAR, OLE and ETH species were found similar for all three cases. As the concentrations of these species did not show any change when Ozone concentration was changing, so it was difficult to find any correlation of these species with $\mathrm{O}_{3}$. It seems for that particular day, these VOCs were not directly contributing to $\mathrm{O}_{3}$ exceedance. This may be explained by the fact that VOCs from biogenic sources also contribute to total Ozone concentration in the ambient air. Figure 4(d) Alkane (ETHA) shows highest concentration at 13:00 hour on June 3, when Ozone is also highest which indicates ETHA probably related with Ozone peaking. In Figures 4(e)-(f), $\mathrm{ALD}_{2}$ and FORM showed higher concentration in the beginning of the mid-day (up to 13:00) when Ozone concentration reaches the peak and then the concentration went down. In studies it have been mentioned that, industrial activities originated FORM (chemically HCHO) works as an appreciable source for Hydroxyl radical $(\mathrm{OH})$ in the morning, where $\mathrm{OH}$ is the most influential chemical for enhanced Ozone production. Among these VOCs, FORM is considered as a vital radical precursor, which leads to form hydroxyl $(\bullet \mathrm{OH})$ and peroxy radicals $\left(\mathrm{HO}_{2} \bullet\right)$ [13]. In $\mathrm{O}_{3}$ photolysis process aldehydes also contribute to provide odd hydrogen $\left(\mathrm{HO}_{\mathrm{x}}\right)$ radicals [20]. So, correlation graph of $\mathrm{ALD}_{2}$ and FORM with Ozone were also plotted. While analyzing these species, concentration of secondary pollutant PAN was also observed because PAN is formed from the reaction of NOx and radicals from VOCs [21]. It is also a major sink in Ozone production process [19] [22] [23]. On the other hand, ETOH, MEOH, TOL, XYL were not found to vary on June 3 for the three cases when they were plotted over the time. So, the correlation graphs of these VOCs with $\mathrm{O}_{3}$ were not further pursued. To evaluate the impact of the VOCs released from the point source emissions, correlation of the specific VOCs with $\mathrm{O}_{3}$ concentration were presented in Figure 5.

VOCs and $\mathrm{O}_{3}$ concentration for case ALL and HGB were used for the correlation graphs (Figure 5) by linear $\mathrm{R}$ squared $\left(\mathrm{R}^{2}\right)$ value. Case WOP was not considered because this emissions scenario did not include any point source emissions. Figure 5(a) for acetaldehyde $\left(\mathrm{ALD}_{2}\right)$ shows $\mathrm{R}$ squared value $\left(\mathrm{R}^{2}\right)$ about $0.809(\sim 81 \%)$ with

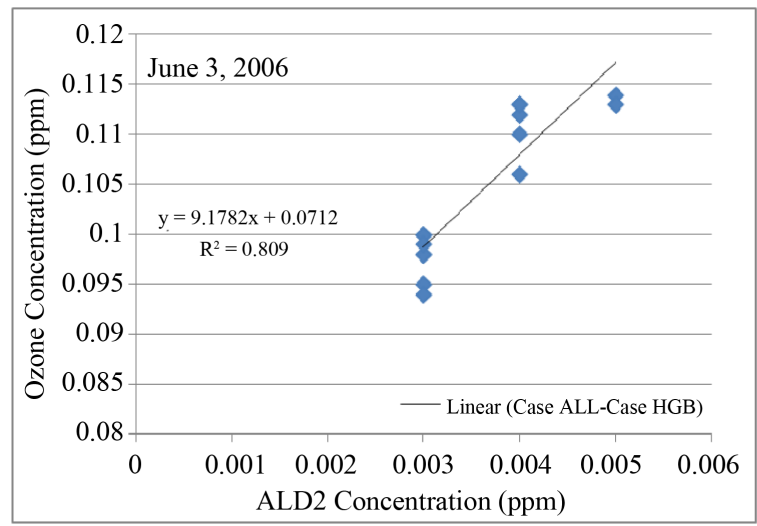

(a)

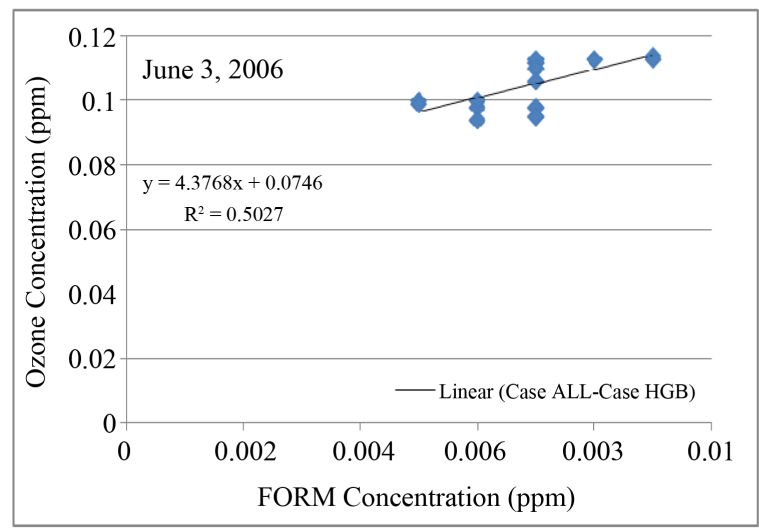

(c)

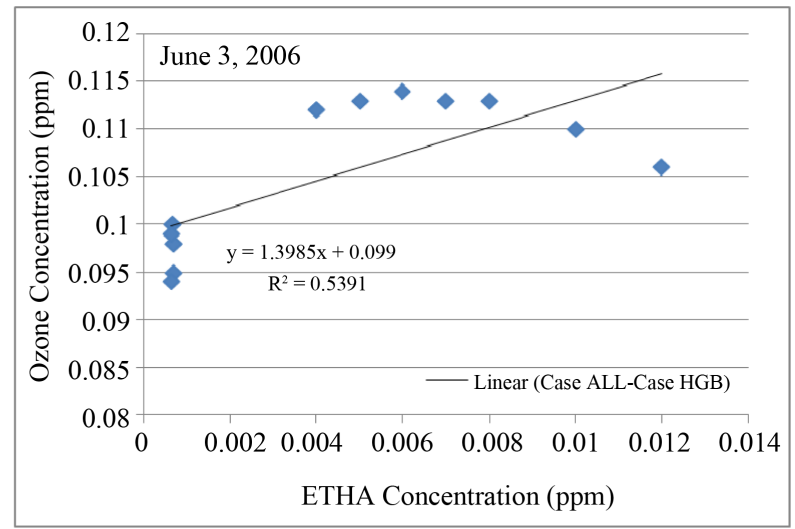

(b)

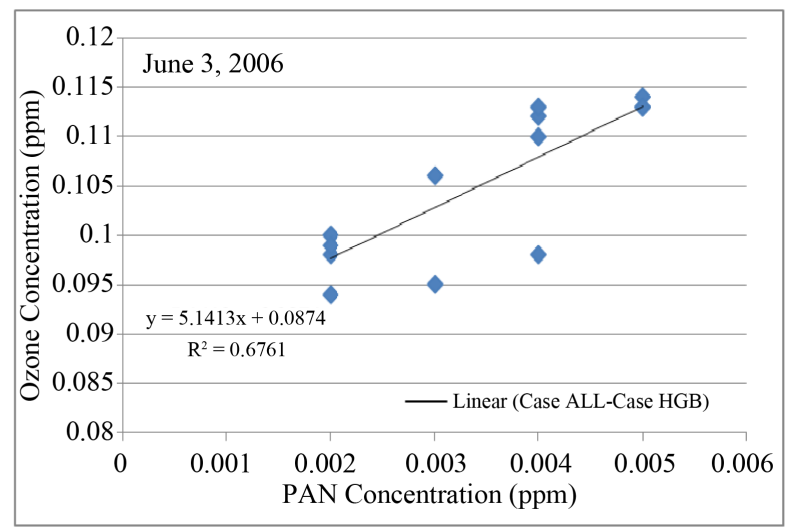

(d)

Figure 5. Co-relationship of VOCs with Ozone formation during time-steps (11:00 - 17:00) for case ALL and case HGB on June 3, 2006. (a) ALD ; (b) ETHA; (c) FORM; (d) PAN. 
Ozone $\left(\mathrm{O}_{3}\right)$. This value reflects that $\mathrm{ALD}_{2}$ was strongly related to higher $\mathrm{O}_{3}$ formation for that day. Figure 5(b) for ethane (ETHA) showed the correlation, $\mathrm{R}^{2}$ is $0.53(\sim 53 \%)$ with Ozone. Figure 5(c) for FORM showed the correlation, $\mathrm{R}^{2}$ is 0.50 ( $\sim 50 \%$ ) with $\mathrm{O}_{3}$. Figure 5(d) PAN showed good correlation, $\mathrm{R}^{2}$ is 0.67 ( $\left.67 \%\right)$ with $\mathrm{O}_{3}$.

Studies reported that emissions from point sources have many chemical compounds, particularly alkanes and aromatics; they are less frequent in the reporting database than alkene releases. Also, Ozone production was directly related to the amount of hydroxyl radicals produced from the photolysis of Formaldehyde and other aldehydes in every simulation [10]. FORM is a key species in understanding ozone related air pollution because some of the highest FORM concentrations in North America have been reported for the Houston-Galveston Air shed [13]. The correlation graphs found in this research work, aldehydes $\left(\mathrm{ALD}_{2}\right)$ with Ozone $\left(\mathrm{O}_{3}\right)$ and FORMwith Ozone $\left(\mathrm{O}_{3}\right)$, agreed with the studies. One important observation was that all these VOCs were positively correlated with $\mathrm{O}_{3}$, which means when there is more of these VOCs emission, there is more chance of $\mathrm{O}_{3}$ production and exceedance.

A study [13] reported that $\mathrm{SO}_{2}$ emissions by source sector for Harris County, which includes Houston and the Houston Ship Channel (HSC), were as follows for the year 2005: industrial processes: $45.5 \%$, fossil fuel combustion: $39.3 \%$, non-road equipment: $9.3 \%$, on road vehicles: $2.9 \%$, waste disposal: $2.2 \%$, solvent use: $0.6 \%$, electricity generation: $0.2 \%$, and residential wood combustion: $<0.1 \%$ [24]. From EPS3 result of case ALL and HGB 2006, it was also found that point sources of HGB area contribute about 32\% of total Sulfur dioxide $\left(\mathrm{SO}_{2}\right)$ emissions in tx_4 km domain. So, there is a possibility that $\mathrm{SO}_{2}$ can affect the Ozone or the VOCs. In Figures 6(a)-(d) the impact of $\mathrm{SO}_{2}$ on the VOCs related to $\mathrm{O}_{3}$ production was illustrated. A study reported that, $\mathrm{SO}_{2}$ from industrial emissions, PAN and CO were found correlated with FORM [13]. As can be seen from Figure 6(a), $\mathrm{SO}_{2}$ showed good correlation with $\mathrm{ALD}_{2}$, the $\mathrm{R}^{2}$ value of about 0.59 (60\%). From Figure 6(b) it seems $\mathrm{SO}_{2}$

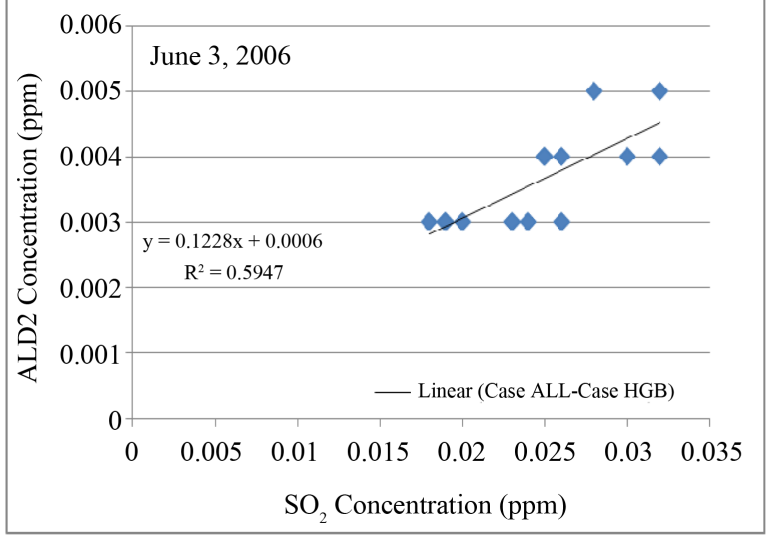

(a)

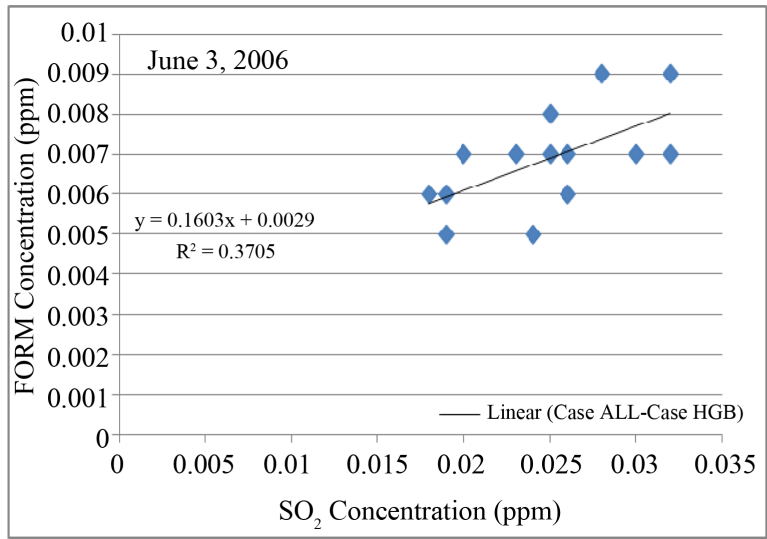

(c)

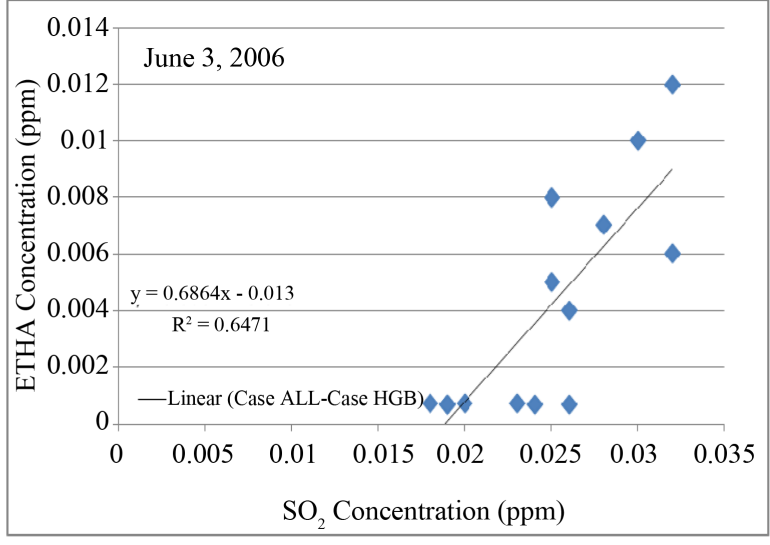

(b)

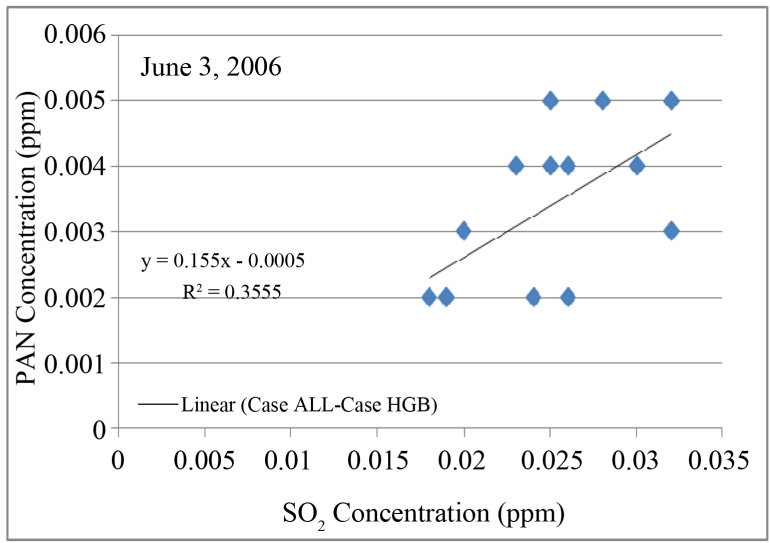

(d)

Figure 6. (a) $\mathrm{ALD}_{2}$ over $\mathrm{SO}_{2}$; (b) ETHA over $\mathrm{SO}_{2}$; (c) FORM over $\mathrm{SO}_{2}$; and (d) PAN over $\mathrm{SO}_{2}$ during time-steps (11:00 17:00) for Case ALL and Case HGB on June 3, 2006. 
is well correlated with ETHA with a $\mathrm{R}^{2}$ value of about 0.65 (65\%). But $\mathrm{SO}_{2}$ showed less correlation with FORM and PAN as shown in Figures 6(c)-(d). This could be the effect of meteorological conditions because Rappengluck [25] reported that $\mathrm{SO}_{2}$ related $\mathrm{HCHO}$ fractions as well as residual $\mathrm{HCHO}$ have a strong dependence on wind direction.

\section{Conclusion}

Point source is one of the major sources of air pollutants which initiates air quality degradation. In this paper the significance of point source emissions on Ozone $\left(\mathrm{O}_{3}\right)$ production was studied using CAMx model output. EPS3 processed emissions files and TCEQ Rider 8 Base-case input files were used. Weekdays (June 1 and June 2) and weekend days (June 3 and June 4) in summer time 2006 for three different scenarios (ALL, TCEQ, WOP) were simulated. While analyzing the reasons behind high $\mathrm{O}_{3}$ formation in $\mathrm{HGB}$ area, $\mathrm{O}_{3}$ sensitivity for the precursors was evaluated. Ratio of hydrogen peroxide to nitric acid $\left(\mathrm{H}_{2} \mathrm{O}_{2} / \mathrm{HNO}_{3}\right)$ showed that $\mathrm{O}_{3}$ formation in $\mathrm{HGB}$ area was NOx limited for the simulated episode. So, control of nitrogen oxides emissions is imperative to control $\mathrm{O}_{3}$ exceedance in HGB area. On the other hand, some VOCs showed good correlations with high Ozone concentrations. $\mathrm{ALD}_{2}$, FORM, ETHA and PAN showed correlation $\left(\mathrm{R}^{2}\right)$ of $0.81,0.53,0.5$ and 0.67 respectively with $\mathrm{O}_{3}$. Sulfur dioxide $\left(\mathrm{SO}_{2}\right)$ was found to have good correlation with the VOCs, such as $\mathrm{ALD}_{2}$ and ETHA. So, reactivity of specific VOC species is significant for $\mathrm{O}_{3}$ exceedence. While considering the emission control strategies these VOCs emissions limit should also be considered along with the NOx. For this study only one episode of summer 2006 was analyzed. To acquire effective results more simulation and analysis is recommended.

\section{Acknowledgements}

This work is supported by the National Science Foundation (NSF) through the Center for Energy and Environmental Sustainability (CEES), a CREST Center, award no. 1036593

\section{References}

[1] Cook, S.K., Parrish, D., Ryerson, T., Nopmongcol, U., Johnson, J., Tai, E. and Yarwood, G. (2009) Contributions of Regional Transport and Local Sources to Ozone Exceedances in Houston and Dallas: Comparison of Results from a Photochemical Grid Model to Aircraft and Surface Measurements. Journal of Geophysical Research, 114.

[2] Texas Commission on Environmental Quality (TCEQ) (2014). http://www.tceq.texas.gov/airquality/sip/hgb/hgb-ozone-history

[3] Sillman, S. (1995) The Use of NOy, $\mathrm{H}_{2} \mathrm{O}_{2}$ and $\mathrm{HNO}_{3}$ as Indicators for Ozone -NOx-Hydrocarbon Sensitivity in Urban Location. Journal of Geophysical Research, 100, 14175-14188.

[4] Lin, C.J., Hob, T.C., Chu, H.W., Yang, H., Chandrub, S., Krishnarajanagar, N., Chioue, P. and Hopperb, J.R. (2005) Sensitivity Analysis of Ground-Level Ozone Concentration to Emission Changes in Two Urban Regions of Southeast Texas. Journal of Environmental Management, 75, 315-323.

[5] Ryerson, T.B., Trainer, M., Angevine, W.M , Brock, C.A., Dissly, R.W., Fehsenfeld, F.C., Frost, G.J., Goldan, P.D., Holloway, J.S., Hübler, G., Jakoubek, R.O., Kuster, W.C., Neuman, J.A., Nicks Jr., D.K., Parrish, D.D. and Senff, C.J. (2003) Effect of Petrochemical Industrial Emissions of Reactive Alkenes and NOX on Tropospheric Ozone Formation in Houston, Texas. Journal of Geophysical Research, 108, 42-49.

[6] Kleinman, L.I., Daum, P.H., Lee, Y.-N., Nunnermacker, L.J., Springston, S.R., Weinstein-Lloyd, J. and Rudolph, J. (2005) A Comparative Study of Ozone Production in Five U.S. Metropolitan Areas. Journal of Geophysical Research, 110.

[7] Nam, J., Kimura, Y., Vizuete, W., Murphy, C. and Allen, D.T. (2006) Modeling the Impacts of Emission Events on Ozone Formation. Atmospheric Environment, 40, 5329-5341.

[8] National Oceanic and Atmospheric Administration (NOAA) (2014) http://www.esrl.noaa.gov/csd/projects/2006/fieldops/emission.html

[9] ENVIRON (2009) User’s Guide: Emission Processor, ENVIRON International Corporation, 1-1, 3-67.

[10] Vizuete, W., Kim, B.-U., Jeffries, H., Kimura, Y., Allenc, D.T., Kioumourtzogloua, M.A., Bitona, L., Henderson, B. (2008) Modeling Ozone Formation from Industrial Emission Events in Houston, Texas. Atmospheric Environment, 42, 7641-7650.

[11] Texas Commission on Environmental Quality (TCEQ) (2004) The State Implementation Plan for the Control of Ozone Pollution: Attainment Demonstration for the Houston/Galveston Ozone Non-attainment Area. 
https://www.tceq.texas.gov/airquality/sip/hgb

[12] Heo, G., McDonald-Buller, E., Carter, W.P.L., Yarwood, G., Whitten, G.Z. and Allen, D.T. (2012) Modeling Ozone Formation from Alkene Reactions Using the Carbon Bond Chemical Mechanism. Atmospheric Environment, 59, 141150. http://dx.doi.org/10.1016/j.atmosenv.2012.05.042

[13] Rappengluck, B., Dasgupta, P.K., Leuchner, M., Li, Q. and Luke, W. (2010) Formaldehyde and Its Relation to CO, $\mathrm{PAN}$, and $\mathrm{SO}_{2}$ in the Houston-Galveston Airshed. Journal of Atmospheric Chemistry and Physics, 10, 2413-2424. http://dx.doi.org/10.5194/acp-10-2413-2010

[14] ENVIRON (2011) Users Guide: Comprehensive Air Quality Model with Extensions. Version 5.40, ENVIRON International Corporation, 3-1, 3-17, 6-10.

[15] Environmental Protection Agency (EPA) (2011) Visualization Environment for Rich Data Interpretation (VERDI 1.4): Users Manual.

[16] Texas Commission on Environmental Quality (TCEQ) (2014) http://www.tceq.texas.gov/airquality/airmod/ rider8/rider8Modeling.

[17] Sarker, S., Liang, Z., Huque, Z. and Kommalapati, R.R. (2013) Impact of Point Sources Emissions on Ozone Formation for Houston Galveston Brazoria (HGB) Area. International Journal of Biological, Ecological and Environmental Sciences, 2, 99-102.

[18] Texas Commission on Environmental Quality (TCEQ) (2009) Protocol for Eight-Hour Ozone Modeling of the Houston/Galveston/Brazoria Area.

[19] Sillman, S., Logan, J.A. and Wofsy, S.C. (1990) The Sensitivity of Ozone to Nitrogen Oxides and Hydrocarbons in Regional Ozone Episodes. Journal of Geophysical Research, 95, 1837-1851. http://dx.doi.org/10.1029/JD095iD02p01837

[20] Sillman, S. (2014) Overview: Tropospheric Ozone, Smog and Ozone-NOx-VOC Sensitivity, University of Michigan. http://www-personal.umich.edu/ sillman/

[21] Rani, B., Singh, U., Chuhan, A.K., Sharma, D. and Maheshwari, R. (2011) Photochemical Smog Pollution and Its Mitigation Measures. Journal of Advance Scientific Research, 2, 28-33.

[22] Kleinman, L.I. (1986) Photochemical Formation of Peroxide in the Boundary Layer. Journal of Geophysical Research, 91, 10889-10904. http://dx.doi.org/10.1029/JD091iD10p10889

[23] Sillman, S. (1991) A Numerical Solution for the Equations of Tropospheric Chemistry Based on an Analysis of Sources and Sinks of Odd Hydrogen. Journal of Geophysical Research, 96, 20735-20744. http://dx.doi.org/10.1029/91JD01967

[24] Environmental Protection Agency (EPA) (2005) Air Emission Sources—Sulfur Dioxide. http://www.epa.gov/air/emissions/so2.htm

[25] Rappengluck, B., Perna, R., Zhong, S. and Morris, G.A. (2008) An Analysis of the Vertical Structure of the Atmosphere and the Upper-Level Meteorology and Their Impact on Surface Ozone Levels in Houston, Texas. Journal of Geophysical Research, 113, 190. http://dx.doi.org/10.1029/2007JD009745 